catory difficulty as increased dietary fibre may aggravate the constipation that is already present.

J A BARRET

Department of Geriatric Medicine,

University of Manchester,

University of Manche
Manchester $\mathrm{M} 68 \mathrm{HD}$

1 Holdstock DJ, Misiewicz JJ, Smith T, Rowlands EN. Propulsio (mass movements) in the human colon and its relationship to meals and somatic activity. Gut 1970;11:91-9.

2 Donald IP, Smith RG, Cruikshank JG, Elton RA, Stoddart ME. A study of constipation in the elderly living at home. Gerontology 1985;31:112-8.

3 Brocklehurst JC, Khan MY. A study of faecal stasis in old age and the use of 'Dorbanex' in its prevention. Gerontologia Clinica 1969;11:293-300

4 Read NW, Timms JM, Barfield LJ, Donnelly TC, Bannister JJ. Impairment of defecation in young women with severe constipation. Gastroenterology 1986;90:53-60.

5 Bannister JJ, Davison P, Timms JM, Gibbons C, Read NW. Effect of stool size and consistency on defaecation. $G u$ 1987;28:1246-50

\section{Modern medicine and war}

SIR,-We were interested that Dr Tony Delamothe's conference report (19 March, p 852) totally ignored the developments in psychiatry which have emerged from the impact of war in this century.

The most obvious example is that of shell shock, which had a considerable effect on the field of psychological medicine and encouraged severa reforms of mental health care during the interwar years. Shell shock brought the neuroses into the mainstream of mental medicine and gave credibility to Freudian theories. Treatments such as "faradisation" - that is, administering painfu electric shocks to the larynx to soldiers with hysterical aphonia-soon became discredited as doctors discovered that psychotherapeutic techniques were far more effective. One of the main exponents of these was W H Rivers, who established Freud's theories in the Royal Army Medical Corps through his influential article in the Lance in $1917 .^{1}$

The large number of ex-servicemen requiring aftercare for shell shock eventually led to the Mental Treatment Act 1930, which empowered local authorities to set up outpatient psychiatric clinics and allowed the mentally ill to be voluntary patients. This was a first move towards the decriminalisation of mental illness which culminated in the Mental Health Act 1959 and laid the ground for the development of psychiatric community care.

S H Foulkes's experience at Northfield Military Hospital during the second world war led him to develop group analytic psychotherapy, which has become a common form of treatment in psychiatric wards. T F Main introduced the term "therapeutic community" in 1946 arising from his experience a Northfield, and this concept of care was developed at the Cassel Hospital where he later worked. In contrast, Sargant has suggested that the second world war gave an important impetus to the development of physical treatments in psychiatry.

The Vietnam war led to several studies on posttraumatic stress disorder and increaseci our know ledge of the psychological consequences of acute stress. The Falklands conflict will probably have similar consequences. ${ }^{3}$

To consider the impact of modern war on medicine without considering the impact of modern war on psychiatry is rather like proposing a production of Hamlet without the prince.

University Department of Psychiatry,

L M LoveTT Liverpool L69 3BX

Countess of Chester Hospital

J W T LOVETT
Rivers WH. Freud's psychology of the unconscious. Lancet 1917;i:912-4

2 Sargant W. The unquiet mind. London: Heinemann, 1967.

3 Jones GH, Lovett JWT. Delayed psychiatric sequelae amo
Passive smoking and lung cancer: a publication bias?

SIR,-Dr Jan P Vandenbroucke (6 February, p 391 ) surmises that there may be some publication bias relative to male data on passive smoking because the data published by Wald $e t$ al do not conform to a "funnel" pattern when measured against the standard error of the natural logarithm of relative risk. Having made some effort to gather unpublished data on passive smoking, I would like to make some comments.

Firstly, there are two minor errors in fig 2. The ordinate is labelled logarithm of relative risk when it is in fact the relative risk itself plotted on a logarithmic scale. Also the open circle at $x=0.4$ and $y=2.25$ should be black since it represents Hirayama's data for men.

Dr Vandenbroucke is correct on two points: there are some unpublished data on men, and male and female data should be treated separately. $\mathrm{He}$ is also correct that authors, confronted with weak data for men alongside stronger data for women, are inclined to drop the former in favour of the latter. These weak male data, however, do not necessarily mean low or negative relative risks.

Two studies in which data on women but not on men were published are those by Humble $e t a l^{2}$ and Brownson et al. ${ }^{3}$ Their unpublished data on men are shown in the table.

In analyses I have made on relative risks of lung cancer from passive smoking I have used a minimum of 10 years' exposure or exposure of a spouse for admission of data (World Conference on Smoking and Health, Tokyo, 1987). Therefore, I prefer the 33+ year exposure data of Buffler $e t a l^{4}$ shown in the table to the $0+$ year exposure data that Wald et $a l^{1}$ used. Also Wald et al used a roundabout method to calculate their 2.45 relative risk for Akiba et al, ${ }^{5}$ which is higher than the odds ratio calculated by Akiba et al from matched analysis $(1 \cdot 8)$ or their crude odds ratio $(2 \cdot 1)$ or "observed" deaths divided by their "expected" deaths of Wald et al (1·7). For Akiba et al I prefer their matched analysis value of 1.8 and have calculated $95 \%$ confidence intervals from their $90 \%$ confidence intervals. Also shown in the table are the data from the other studies in men that Vandenbroucke took from Wald et al.

If one plots the relative risk data in the table on a logarithmic scale against the standard error of $\ln (R R)$ as calculated by Dr Vandenbroucke one gets a funnel shaped distribution centred on a relative risk of $2 \cdot 06$, which is the value one gets by aggregatung the relative risk data using the method of Blot and Fraumeni. ${ }^{6}$ The relative risks from the two unpublished studies are higher than the combined relative risk, not lower as Vandenbroucke expected. Excluding them from the analysis reduces the com-

assive smoking relative risk for lung cancer versus standard error of $\ln (R R)$ in men

\begin{tabular}{|c|c|c|c|c|c|c|c|}
\hline \multirow[b]{2}{*}{ Authors } & \multicolumn{2}{|c|}{ Exposed to smoke } & \multicolumn{2}{|c|}{ Not exposed } & \multirow[b]{2}{*}{$\begin{array}{l}\text { Relative } \\
\text { risk }\end{array}$} & \multirow{2}{*}{$\begin{array}{c}95 \% \\
\text { Confidence } \\
\text { interval }\end{array}$} & \multirow{2}{*}{$\begin{array}{l}\text { Standard error } \\
\text { of } \ln (\mathrm{RR}) \text { as } \\
\text { calculated by } \\
\text { Vandenbroucke }\end{array}$} \\
\hline & $\begin{array}{l}\text { Lung } \\
\text { cancer }\end{array}$ & $\begin{array}{l}\text { No lung } \\
\text { cancer }\end{array}$ & $\begin{array}{l}\text { Lung } \\
\text { cancer }\end{array}$ & $\begin{array}{l}\text { No lung } \\
\text { cancer }\end{array}$ & & & \\
\hline \multicolumn{8}{|l|}{ Unpublished data } \\
\hline Humble et $a l^{\star}$ & 5 & 37 & 3 & 93 & $4 \cdot 2$ & 1.0 to 16.8 & $0 \cdot 72$ \\
\hline Brownson et $a l^{\star}$ & 3 & 10 & 1 & 9 & $2 \cdot 7$ & 0.2 to 31 & $1 \cdot 29$ \\
\hline \multicolumn{8}{|c|}{$\begin{array}{l}\text { Relative risks changed from } \\
\text { Wald } \text { et } a l^{1}\end{array}$} \\
\hline Buffler $e t a l^{4}$ & $2 \star$ & $8^{\star}$ & $6^{\star}$ & $34^{\star}$ & $1 \cdot 6$ & 0.30 to 8.05 & 0.84 \\
\hline Akiba $e t a l^{5}$ & 3 & 9 & 16 & 101 & $1 \cdot 8$ & 0.44 to 7.46 & $0 \cdot 73$ \\
\hline \multicolumn{8}{|c|}{ As reported by Wald $e t a l^{1}$} \\
\hline Correa et al & 2 & 26 & 6 & 154 & $2 \cdot 29$ & 0.30 to 17.33 & 1.03 \\
\hline Kabat and Wynder & 5 & 5 & 7 & 7 & $1 \cdot 00$ & 0.20 to 5.06 & 0.82 \\
\hline Lee $e t a l$ & 8 & 14 & 7 & 16 & $1 \cdot 30$ & 0.37 to 4.54 & 0.64 \\
\hline Gillis et al & 4 & 306 & 2 & 515 & $3 \cdot 25$ & 0.60 to 17.65 & 0.86 \\
\hline Hirayama & 7 & 1003 & 57 & 19222 & $2 \cdot 25$ & 1.04 to 4.86 & $0 \cdot 40$ \\
\hline Combined relative risk & & & & & 2.06 & 1.31 to 3.22 & $0 \cdot 23$ \\
\hline
\end{tabular}

$\star$ Private communication bined relative risk to $1 \cdot 86$. Using the data on men in Wald et al as is (Buffler et al and Akiba et al unchanged) yields a broader funnel centred on a combined relative risk of $1 \cdot 5$. Adding the two unpublished studies raises this relative risk to $1 \cdot 7$. In either case, on the basis of evidence so far available, there is no indication that publication bias explains or will explain the observed relative risk among men for lung cancer from passive smoking.

From the above discussion it can be seen that the combined relative risk is quite different for the two sexes: a $100 \%$ increase for men (or $70 \%$ by adding the two new studies to the analysis of Wald $e t$ al) versus only a $35 \%$ increase for women (according to Wald $e t$ $a l)$ or $40 \%$ using a more selective and updated analysis. ${ }^{4}$

In conclusion, it is unlikely that publication bias-that is, the suppression of work with high standard errors by authors or reviewers-has any substantial effect on the relative risks that have been calculated from published reports for passive smoking for either men or women. If any investigators have data on passive smoking, however, particularly for men, that have not been published or that they have not been able to get published I would be interested in receiving them for a possible subsequent report.

A JUDSON WELLS

102 Kildonan Glen,

Wilmington, DE 19807 , USA

Wald NJ, Nanchanal K, Thompson SG, Cuckle HS. Does breathing other people's tobacco smoke cause lung cancer? BrMed J 1986;293:1217-22.

2 Humble CG, Samet JM, Pathak DR. Marriage to a smoker and lung cancer risk. Am f Public Health 1987;77:598-602.

3 Brownson RC, Reif JS, Keefe TJ, Ferguson SW, Pritzl JA. Risk factors for adenocarcinoma of the lung. Am $\mathcal{J}$ Epidemiol 1987; 125:25-34.

4 Buffler PA, Pickle LW, Mason TJ, Contant C. The causes of lung cancer in Texas. In: Mizell M, Correa P, eds. Lung cancer: causes and prevention. New York: Verlag Chemie International, 1984:83-99.

5 Akiba S, Kato H, Blot WJ. Passive smoking and lung cancer among Japanese women. Cancer Res 1986;46:4804-7.

Blot WJ, Fraumeni JF. Passive smoking and lung cancer f Natl Cancer Inst 1986;77:993-1000.

\section{The Biopty cut procedure for renal biopsies}

SIR,-The report by Dr Jennifer Donald and others (27 February, p 606) of the use of the Biopty gun (Henleys Medical Supplies, London) in AIDS patients has encouraged us to report our experience with the gun for biopsies of both native and transplant kidneys. Lindgren described the equipment and has reported on its use for biopsy of a wide range of organs, including the kidney, combined usually with ultrasonic imaging.

This new spring trigger device shoots a modified Tru-Cut needle with both the cannula and obturator in a high speed simulation of a manual 
biopsy. The main advantage is the speed and accuracy of needle operation when the specimen is taken.

Although both the machine and manual needles are of similar gauge and notch size-14 gauge and $200 \mathrm{~mm}$ respectively-generally a larger piece of tissue is obtained with the automated system. For example, one core was taken from the same kidney with each technique: the diameters were $1 \cdot 15$ and $1.00 \mathrm{~mm}$ for the automated and manual systems respectively. Using the device with a smaller gauge needle, serial multiple specimens can be taken in the transplanted kidney, making this an alternative to fine needle aspiration for the investigation of suspected rejection. The use of the gun in transplanted kidneys is well reported. ${ }^{2}$

The gun can be used singlehandedly, allowing ultrasonic imaging to be carried out by one operator. The only disadvantage is that it is a more expensive technique as the modified needle for the gun costs more. The gun can be sterilised for use in the operating room, but the needles are not reusable.

This is a major improvement on manual percutaneous renal biopsy, and the technique should be more widely known.

J C MACKENZIE

I G MACKAY

N D MillaR

A G MACIVER

J B PENRY

Department of Nephrology,

Southmead General Hospital,

Bristol BS10 5NB

1 Lindgren PG. Percutaneous needle biopsy. Acta Radiol [Diagn] 1982;23:653-6.

2 Ubhi CS, Irving HC, Guillon PJ, Giles GR. A new technique for renal biopsy. Br F Radiol 1987;60:599-600.

\section{Health of long term benzodiazepine users}

SIR,-In France, as in Britain, benzodiazepines are the most commonly prescribed psychotropic drugs, accounting for a third of all those prescribed.

In January 1984 we carried out a study in which all patients admitted to an internal medicine unit were asked about benzodiazepine use during the previous year. ${ }^{1}$ Alcohol, tobacco, and concurrent drug consumption and past illnesses and operations were also recorded. There were 129 patients, and 49 were identified as benzodiazepine users; the remaining 80 had not used benzodiazepines in 1983. Twenty four of the users were long term users (daily intake of at least one benzodiazepine for over four months) and 25 intermittent users (less than four months' use). Seventeen of the long term users had taken the drugs for over a year.

Users and non-users did not differ in sex ratio, and tobacco and alcohol consumption was similar in non-users, long term users, and intermittent users. The long term users were predominantly elderly. The users had had substantially more

Characteristics of the three groups of patients

\begin{tabular}{|c|c|c|c|c|c|c|}
\hline & \multirow[b]{2}{*}{$\begin{array}{c}\text { Total } \\
(n=129)\end{array}$} & \multirow{2}{*}{$\begin{array}{c}\text { Long term } \\
\text { users }(n=24) \\
(1)\end{array}$} & \multirow{2}{*}{$\begin{array}{l}\text { Intermittent } \\
\text { users }(\mathrm{n}=25) \\
(2)\end{array}$} & \multirow{2}{*}{$\begin{array}{c}\text { Non-users } \\
(\mathrm{n}=80) \\
(3)\end{array}$} & \multicolumn{2}{|c|}{ p Value } \\
\hline & & & & & $1+2 v 3$ & $1 v 3$ \\
\hline \multicolumn{7}{|c|}{ Cardiovascular and rheumatological diseases: } \\
\hline $\begin{array}{l}\text { Present } \\
\text { Absent }\end{array}$ & $\begin{array}{l}89 \\
40\end{array}$ & $\begin{array}{r}19 \\
5\end{array}$ & $\begin{array}{r}20 \\
5\end{array}$ & $\begin{array}{l}50 \\
30\end{array}$ & $<0.05$ & NS \\
\hline \multicolumn{7}{|c|}{ Past operations: } \\
\hline $\begin{array}{l}<2 \\
\geqslant 2\end{array}$ & $\begin{array}{l}93 \\
36\end{array}$ & $\begin{array}{l}14 \\
10\end{array}$ & $\begin{array}{l}11 \\
14\end{array}$ & $\begin{array}{l}68 \\
12\end{array}$ & $<0.001$ & $<0.005$ \\
\hline \multicolumn{7}{|c|}{ Associated drugs: } \\
\hline $\begin{array}{l}<3 \\
\geqslant 3\end{array}$ & $\begin{array}{l}98 \\
31\end{array}$ & $\begin{array}{l}12 \\
12\end{array}$ & $\begin{array}{r}18 \\
7\end{array}$ & $\begin{array}{l}68 \\
12\end{array}$ & \multirow[t]{2}{*}{$<0.001$} & $<0.001$ \\
\hline \multicolumn{6}{|c|}{ Other psychotropic drugs: } & \\
\hline $\begin{array}{l}\text { Yes } \\
\text { No }\end{array}$ & $\begin{array}{r}21 \\
108\end{array}$ & $\begin{array}{r}9 \\
15\end{array}$ & $\begin{array}{r}5 \\
20\end{array}$ & $\begin{array}{r}7 \\
73\end{array}$ & $<0.005$ & $<0.001$ \\
\hline
\end{tabular}

medical conditions and surgical procedures than the non-users, and there was a strong association between use of benzodiazepines and concurrent drug use (table). Cardiovascular and musculoskeletal disorders were the most common diseases in the users. Among the long term users the drug had been prescribed for insomnia (6) or anxiety (6), or both (12). Generalists had more often prescribed them than psychiatrists, though psychiatric morbidity had been found in 11 patients. Seven patients had a diagnosis of depression.

Our data agree with those of Dr E K Rodrigo and others (27 February, p 603), although the prevalence of long term use was lower in their study $(2 \cdot 2 \%)$ and in that of Dr Kevin Morgan and others (p 601) (11.2\%) than in ours (18.6\%). This difference might be due to the fact that we studied inpatients, who have a higher rate of chronic diseases than outpatients. Nevertheless, like Dr Rodrigo and others, we found a strong association between benzodiazepine use and concurren psychotropic and non-psychotropic drug use, and in both studies cardiovascular and rheumatological diseases were the most commonly associated illnesses. Our long term users had had more surgical procedures, however, and this was the only difference between our long term and our intermittent users.

P HALFON

P LE BRAS

I LE GOC

Departments of Internal Medicine

A Mathieu-Boue and Psychiatry, Hòpital de Bicetre, 94275 Le Kremlin Bicetre Cedex France

1 Le Goc I, Feline A, Frebault D, Le Bras Ph, Caquet R. Caracteristiques de la consommation de benzodiazepines che des patiants hospitalisés dans un service de médecine interne. Encephale 1985;ii:1-6.

\section{A better deal for senior house officers}

SIR,-As vocational training scheme course organisers we wholeheartedly agree with the leading article by Stella Lowry (27 February, p 590). Since the inception of the Derby scheme in 1973 a half day release course has operated for all trainees in hospital posts and in general practice for about 30 weeks each year, and there have always been problems of trainees in some hospital posts being released to attend these meetings. We do not expect $100 \%$ attendance but would suggest that 60 $70 \%$ should be possible. In practice, however, some senior house officers manage only $10-20 \%$ of sessions. When we question why this is so we are told that service commitment or staff shortages have prevented their attendance. This problem has not lessened with the large increase in hospital staffing or with personal approaches to the consultants concerned, despite them all agreeing in principle to allow their senior house officers to attend. If we press the argument home on educational grounds we are often met with the answer that the post can always be withdrawn from the scheme.

To introduce educational aims and set sessions for all senior house officers is of paramount importance but will come about only through the colleges asking to see the educational plans that consultants have constructed for their senior house officers on visits to reapprove posts for training purposes, asking the doctors concerned whether tutorial time is made available, and, more importantly, encouraging consultants to attend courses on learning and teaching.

A H MEAKIN

D G MACARTHUR

P MARKS

Derbyshire Royal Infirmary,

M ROWAN-ROBINSON

Derby DE1 2QY

\section{Medical researchers in general practice}

SIR,_-Dr Richard Smith's excellent article Medical researchers training and straining (26 March, p 920) has prompted me to write about the position of general practice research.

About $40 \%$ of all doctors in Britain are general practitioners and nearly all the people of Britain have a family doctor. About $96 \%$ of consultations are dealt with completely by the general practitioner, and only $4 \%$ are referred for a specialist's opinion. A very wide range of clinical medicine is seen by the general practitioner, giving considerable opportunity for research. The academic standards of new entrants to general practice are higher than ever. More high flyers are coming into general practice out of choice, and there is now no shortage of doctors who would be potentially good research workers.

The best way of learning research skills is to do research with the advice and help of experienced colleagues. General practice is now represented in every medical school in the country, in 16 with professorial departments, where research can be carried out in professional surroundings, with the facilities of a library, computing, and statistics. Research is carried out by the academic staff as well as research fellows and often funded by outside bodies. The Royal College of General Practitioners is at present offering research fellowships to allow a general practitioner to carry out research in this way. Most research, however, is carried out in the doctor's own practice, where he would also have a full clinical commitment. It is reasonable that a good study should be supported financially so that, in addition to paying the running expenses of a study, money should be made available to buy some of the doctors' time, so that partners are not penalised for the necessary absences of their researching partner.

One of the best ways of learning research methods in general practice, without being attached to an academic department, is to write an MD thesis. It is difficult to accept this challenge and at the same time have a clinical commitment but it can be done provided the doctor has the will and determination to do it.

In two studies of MD theses from British medical schools in 1958-72 an average of just over $3 \%$ were from general practice. ${ }^{12}$ The reasons given by the general practitioners for writing a thesis seemed to be more to do with the challenge to their intellectual ability than for any personal gain; $86 \%$ of the doctors in the two studies had carried on doing research afterwards.

Good thinkers, especially if they are determined and dedicated, are rare, and they should be en- 